\title{
Pulmonary veno-occlusive disease in childhood-a rare disease not to be missed
}

\author{
Marc Pfluger, Tilman Humpl \\ Department of Pediatrics, Children's Hospital, Inselspital, University of Berne, Berne, Switzerland \\ Contributions: (I) Conception and design: All authors; (II) Administrative support: None; (III) Provision of study materials or patients: None; (IV) \\ Collection and assembly of data: None; (V) Data analysis and interpretation: None; (VI) Manuscript writing: All authors; (VII) Final approval of \\ manuscript: All authors. \\ Correspondence to: Tilman Humpl, MD, PhD. Department of Pediatrics, Children's Hospital, Inselspital, University of Berne, Freiburgstrasse 16, CH \\ 3010 Berne, Switzerland. Email: tilman.humpl@insel.ch.
}

\begin{abstract}
Pulmonary veno-occlusive disease (PVOD) is a rare disease leading to pulmonary hypertension and potentially death related to right heart failure and/or respiratory insufficiency. Clinical symptoms are heterogenous and nonspecific: fatigue, decreased exercise tolerance, shortness of breath on exertion, cough, dizziness, chest pain with exercise, palpitations, syncope, as well as nonspecific symptoms such as headache, poor appetite, pallor or perioral cyanosis. Mutations in the EIF2AK4 (eukaryotic translation initiation factor 2-alpha kinase 4) have been recently described, other risk factors include exposure to organic solvent and trichloroethylene, tobacco exposure and chemotherapy. Echocardiography helps to estimate right ventricular systemic pressure, but further diagnostic workup includes cardiac catheterization to confirm pulmonary hypertension and increased pulmonary vascular resistance. High-resolution computed tomography reveals typical findings: centrilobular ground-glass nodules or opacities, septal lines, thickened interlobular septa, mosaic perfusion, and lymphadenopathy. Histology remains the gold standard, but carries risks for the patient. Proper workup is essential in order to avoid incorrect diagnosis. Pulmonary hypertension targeted treatment has been used in patients with PVOD, however, experience is limited, vasodilatory effects on pulmonary vasculature may lead to deterioration of the patients and should be used with great caution. Lung transplantation is currently the only valid treatment option for patients with PVOD. With prolonged waiting time and progression of the disease mechanical support could be considered.
\end{abstract}

Keywords: Pulmonary hypertension; pulmonary veno-occlusive disease (PVOD); pulmonary edema; ground-glass opacities

Submitted Mar 04, 2020. Accepted for publication May 27, 2020.

doi: $10.21037 / \mathrm{cdt}-20-320$

View this article at: http://dx.doi.org/10.21037/cdt-20-320

\section{Introduction}

Pulmonary veno-occlusive disease (PVOD) is a rare and potentially life-threatening disease, occurring more frequently in children and young adults, but has been diagnosed also in elderly individuals. Höra first described the pathological features of the disease in an adult patient (1). Further reports confirmed common clinical and histological features which were different from classical pulmonary hypertension $(2,3)$. The pathological hallmark of the disorder is progressive occlusion of the small pulmonary veins within the lobular septa by fibrous tissue and intimal thickening, in contrast to larger pulmonary veins which are rarely involved (Figure 1). There are also findings of patchy capillary proliferation. Lantuéjoul et al. suggested that pulmonary capillary hemangiomatous $(\mathrm{PCH})$ is a reactive process, often secondary to PVOD, not always representing a specific entity (4).

According to the most recent and updated classification (6th World Symposium on Pulmonary Hypertension, Nice 


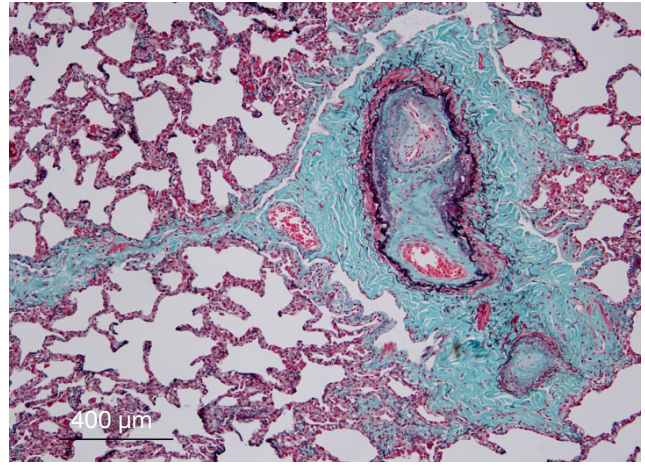

Figure 1 Histologic image from a patient with PVOD (elastic trichrome) showing fibrous obliteration of a pulmonary vein. PVOD, pulmonary veno-occlusive disease.

2018) PVOD is part of group 1 , together with PCH and not a distinct subgroup as in previous classifications (5).

The actual incidence of PVOD is unknown, unfortunately many patients are potentially not correctly diagnosed and labeled as idiopathic pulmonary hypertension (6). The annual incidence of PVOD is estimated at 0.1 to 0.2 cases per million with many cases misdiagnosed as other etiologies of idiopathic pulmonary hypertension. Up to $10 \%$ of patients initially diagnosed with idiopathic $\mathrm{PAH}$ are in the later course of the disease found to have PVOD, and close to $90 \%$ of patients diagnosed with different forms of PAH but not satisfactorily responding to therapy had PVOD $(7,8)$. In a large pediatric pulmonary hypertension registry [Tracking Outcomes and Practice in Pediatric Pulmonary Hypertension (TOPP)] (9), PVOD was only diagnosed in $6 / 456$ patients $(2 \%)$ which may reflect underdiagnosis of the disease.

The first pediatric patient was reported in 1967 (10) followed shortly after by another case report (11). Larger series in pediatric patients with PVOD are rare, Woerner et al. (12) presented in a retrospective analysis 9 patients and a mean age of 13.5 (range, 8-16) years, followed by the definitive diagnosis of PVOD at a mean age of 14.3 (range, 10-16) years.

Substantial data on the natural history of PVOD are not available. The disease process usually shows rapid and steady progression, with very guarded prognosis which is worse than other forms PAH. In adult patients the mortality rate was estimated with $72 \%$ within 1 year of diagnosis (13). From a French registry it was suggested that the mean time from diagnosis to death or lung transplantation was approximately 1 year, whereas the mean time from first symptoms to death or lung transplantation was about 2 years (14). In a case report of an adult patient PVOD was diagnosed at autopsy, but typical signs on computed tomography had been noted earlier, leading to an over 15 years survival after initial presentation (15), despite the generally known poor prognosis of PVOD. The pediatric experience is a mean survival after diagnosis of approximately 14 months (12).

We attempted a search of pediatric patients with PVOD in the literature, using PubMed ("pulmonary veno-occlusive disease", languages: English, French, German, Spanish, December 2019). We were able to identify a total of 68 of patients under 18 years of age. There are unfortunately limitations: not all authors provided a clear history of the patients, diagnostic tools used were different, not every diagnosis was confirmed by histology, outcome data are missing and patient data were used in multiple publications (Table 1).

\section{Clinical presentation}

Patients with PVOD may present with fatigue, decreased exercise tolerance, shortness of breath on exertion, cough, dizziness, chest pain with exercise, palpitations, syncope, but also nonspecific symptoms such as headache, poor appetite, pallor or perioral cyanosis, leading with disease progression to various manifestations of right heart and/or respiratory failure. There also a pediatric patient that presented with massive alveolar hemorrhage (17).

\section{Etiology}

Wagenvoort et al. speculated that PVOD in a newborn developed on the basis of thrombosis prenatally (49), following similar contemporary concepts $(3,50,51)$.

Initially PVOD was thought to be a sporadic disease, however, with time several reports suggested familial occurrence $(18,40,47,52)$.

More recently mutations in the EIF2AK4 (eukaryotic translation initiation factor 2-alpha kinase 4) gene coding for a serine/threonine-protein kinase were found to be a main cause of heritable PVOD (53). In 13 affected families, 3 patients belonged to the pediatric age group. Variants of unknown significance were also associated in one patient with PVOD and mutations of the bone morphogenetic protein receptor type II (54).

The documentation of the mutations as a main reason for inheritable PVOD endorses the genetic basis of this type of 
Table 1 Pediatric patients with PVOD reported in the literature

\begin{tabular}{|c|c|c|c|}
\hline Author & Age at diagnosis & History, risk factors & Mode of diagnosis \\
\hline Bürki (2) & 15 years & Unknown & Autopsy \\
\hline Cohn (17) & 6 years & Unknown & Histology (open lung biopsy) \\
\hline Davies (18) & 13 years & Unknown, possibly heritable (sibling) & Histology \\
\hline Davis (19) & 17 years & Unknown & Computed tomography and histology \\
\hline \multirow[t]{3}{*}{ Day (20) } & 6 years & Heritable & Autopsy \\
\hline & 8 years & Juvenile idiopathic arthritis & Computed tomography \\
\hline & 9 years & Heritable & Autopsy \\
\hline \multirow[t]{2}{*}{ Hackman (23) } & 4 years & $\begin{array}{l}\text { Acute lymphoblastic leukemia (chemotherapy: vincristine, } \\
\text { prednisone, asparaginase, daunomycin and methotrexate), } \\
\text { bone marrow transplantation }\end{array}$ & Histology (open lung biopsy) \\
\hline & 4 years & $\begin{array}{l}\text { Acute lymphoblastic leukemia (chemotherapy: vincristine, } \\
\text { prednisone, asparaginase and methotrexate), bone marrow } \\
\text { transplantation }\end{array}$ & Clinically \\
\hline Heath (24) & 5 years & Repeated bronchitis and chest infection & Histology \\
\hline Holcomb (13) & 9 years & Unknown & Computed tomography \\
\hline Hussein (25) & 12 years & Antiphospholipid syndrome & Unknown \\
\hline Justo (27) & 5 months & Unknown & Autopsy \\
\hline Kano (28) & 11 years & Unknown & Autopsy \\
\hline \multirow[t]{3}{*}{ Kawashima (29) } & 7 months & $\begin{array}{l}\text { Acute lymphoblastic leukemia (chemotherapy: busulfan, } \\
\text { cyclophosphamide, etoposide), stem cell cord blood }\end{array}$ & Computed tomography \\
\hline & 4 years & $\begin{array}{l}\text { Acute lymphoblastic leukemia (chemotherapy: } \\
\text { cyclophosphamide, etoposide, carmustine), stem cell } \\
\text { transplantation }\end{array}$ & Computed tomography \\
\hline & 2 years & $\begin{array}{l}\text { Neuroblastoma (chemotherapy: carboplatin, etoposide, } \\
\text { melphalan), stem cell transplantation }\end{array}$ & Computed tomography \\
\hline Liang (30) & 5 years & Congenital heart disease (tetralogy of Fallot) & Cardiac catheterization \\
\hline Liebow (31) & \multicolumn{2}{|c|}{5 patients $<16$ years Unknown } & - \\
\hline Lombard (32) & 17 years & Malignant glioma (chemotherapy: carmustin) & $\begin{array}{l}\text { Histology (open lung biopsy) and } \\
\text { autopsy }\end{array}$ \\
\hline
\end{tabular}

Table 1 (continued) 
Table 1 (continued)

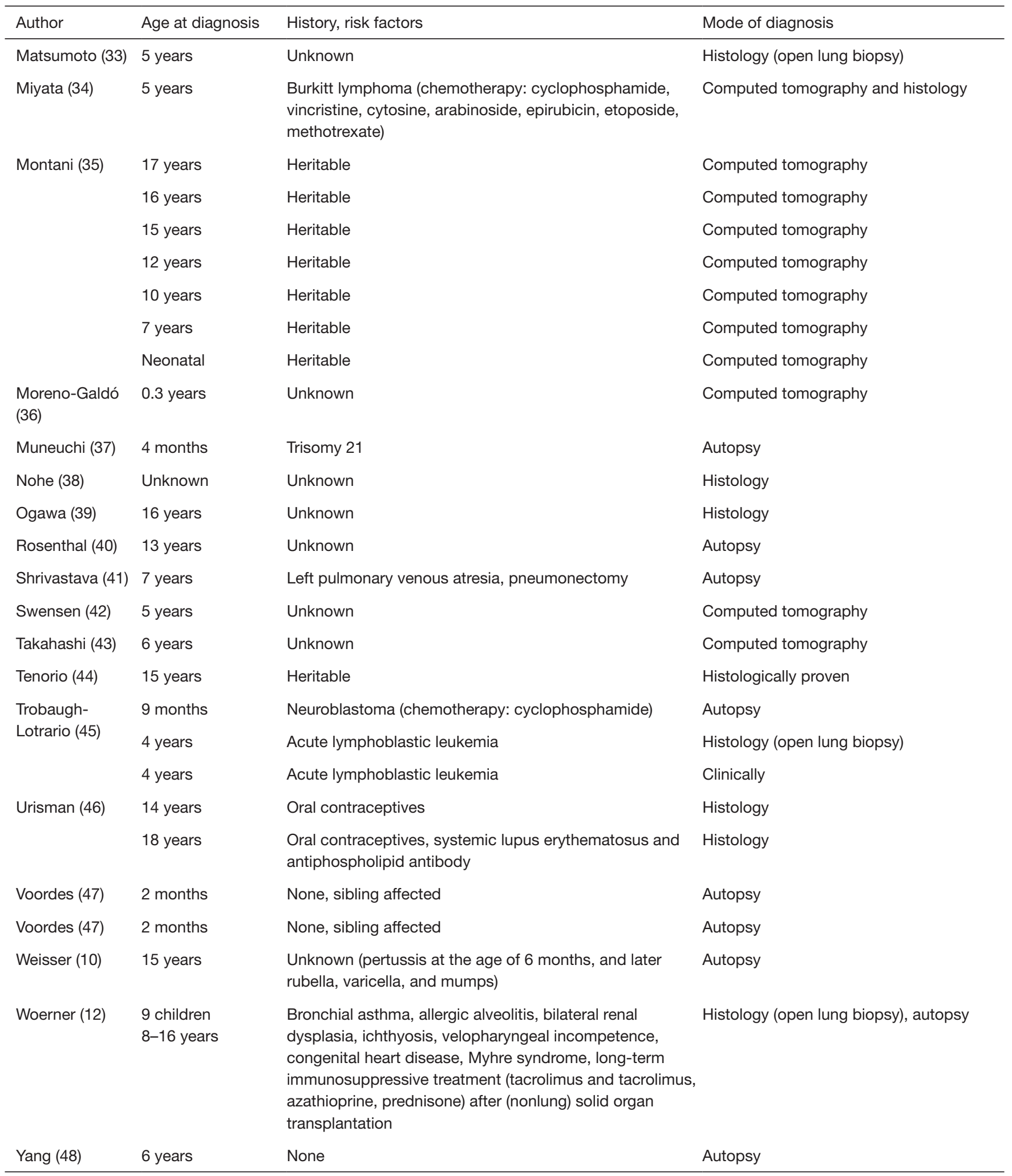

PVOD, pulmonary veno-occlusive disease. 


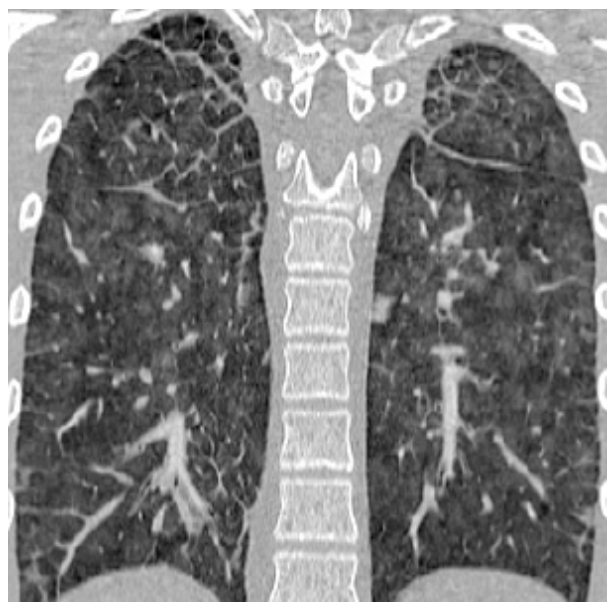

Figure 2 Computed tomography (coronal plane) showing diffuse ground-glass opacity with a mosaic pattern, thickened septal lines extending to the pleura.

pulmonary hypertension. Mutation identification will allow genetic counseling to be offered to families affected by the disease. These results also open new research avenues into the role of EIF2AK4 in pulmonary vascular remodeling and pave the way for innovative therapeutic strategies.

Possible risk factors for the development of PVOD include exposure to organic solvent and trichloroethylene (55), tobacco exposure (14), chemotherapy (including bleomycin, doxorubicin, epirubicin, methotrexate, vincristine, mitomycin-C and etoposide) (34,56-58) and/or radiation therapy $(32,59)$.

Zinter et al. (60) highlight the increasing evidence for a wide spectrum of pulmonary vascular disease after pediatric hematopoietic stem cell transplant. While the majority of post hematopoietic stem cell transplant pulmonary vascular disease has been thought to be pulmonary arterial hypertension, PVOD must be considered as a differential diagnosis well. A recent publication reviewed children with pulmonary hypertension after bone marrow transplantation, however, only $3 / 22$ patients underwent lung biopsy without histological findings of PVOD (61).

Other conditions more frequently occurring in adults than children have been linked with PVOD including scleroderma, pulmonary Langerhans cell histiocytosis, sarcoidosis and Hashimoto's thyroiditis (62-69). However, an adolescent with antiphospholipid antibody syndrome was also diagnosed with PVOD (25). Muneuchi et al. described an infant with trisomy 21 , which showed normal lung histology at 2 months of age and had developed PVOD at
5 months of age (37).

Chetty et al. reported 6 patients with PVOD and hypertrophic cardiomyopathy, suggesting a genetic link between the two entities (70).

\section{Diagnosis}

As PVOD causes pulmonary hypertension, echocardiography will be helpful to estimate right ventricular systemic pressure, provides information about right (and left) ventricular function, and rules out forms of congenital heart disease. Further diagnostic workup includes cardiac catheterization to confirm pulmonary hypertension and increased pulmonary vascular resistance with normal pulmonary capillary wedge pressure. The diagnosis of PVOD may be suspected based on clinical and radiologic data. The chest X-ray is of limited value, whereas high-resolution computed tomography reveals the typical findings (Figure 2): centrilobular ground-glass nodules or opacities, septal lines, thickened interlobular septa, mosaic perfusion, and lymphadenopathy (71-75). Pleural effusion is less consistently found (72). However, patients with idiopathic $\mathrm{PAH}$ and $\mathrm{PAH}$ associated with connective tissue disease may also present with similar findings. Other findings include fluid accumulation in airspaces and local alveolar collapse. Classic changes of PVOD may be more pronounced in certain areas of the lungs compared to others.

A recent study demonstrated that patients with EIF $2 A K 4$ mutation tend to have a higher frequency of mediastinal lymphadenopathy and interlobular septal thickening on computed tomography (76).

Fiberoptic bronchoscopy with bronchoalveolar lavage may reveal hemosiderosis occult alveolar hemorrhage related to post-capillary blockage (77).

Ventilation-perfusion studies usually show normal ventilation and frequently display only focal areas of hypoperfusion. If discrepancy exists between ventilationperfusion scan and pulmonary angiogram a high index of suspicion for PVOD is required (78).

Definite diagnosis requires pathological evaluation. However, open lung biopsy which is necessary for the histologic analysis carries substantial risks in patients with pulmonary hypertension (79). Perioperative complications for children with pulmonary hypertension are known (80), hence, risks and benefits for the patient should be individually assessed. The non-invasive diagnostic approach may avoid the lung biopsy (81) and should include: very low $\mathrm{D}_{\mathrm{LCO}}$, resting hypoxemia, severe desaturation with 
exercise, at least two characteristic radiological signs on high resolution computed tomography and occult alveolar hemorrhage on bronchoalveolar lavage. Hemosiderinladen macrophages in the sputum of patients with PVOD is significantly higher compared to other forms of $\mathrm{PH}$ which may be used for non-invasive diagnostic work-up (82). Kano et al. reported on an 11-year-old girl with hypoxia and abnormal chest radiographic findings, centrilobular groundglass opacities on computed tomography, macrophages consisting mainly of hemosiderin-laden cells, diagnosed and treated for interstitial lung disease, and a postmortem diagnosis of PVOD (28).

It remains absolutely mandatory that children with pulmonary hypertension receive a complete workup. In a recent publication with a large cohort of pediatric patients less than half of the patients diagnosed with pulmonary hypertension had undergone computed tomography (83), which leaves the suspicion of undetected diagnosis of PVOD in this patient group.

Ogawa et al. developed a score including representative parameters (clinical data and radiological findings) which may be useful to establish an early clinical diagnosis (84). However, this has not been used or validated in children.

\section{Treatment}

Lung transplantation is currently the only treatment option for patients with PVOD. As the waiting time for organs may be prolonged, mechanical support could be considered. Extra-corporeal membrane oxygenation (85) (venoarterial or venovenous) may help with oxyenation without or with atrial septostomy (unloading the right ventricle) but has limitations due to potential complications (bleeding, infection). More recently the iLA Membrane Ventilator (Xenios, Germany) has been used with cannulation of the pulmonary artery and right pulmonary vein, using the right ventricle as the pump with the device outside of the body (86).

The experience with the use of pulmonary hypertension targeted treatment is limited. Hoeper et al. (87) documented that inhaled nitric oxide and aerosolized iloprost had almost no effect on pulmonary arterial pressure but caused significant increase of cardiac output and a drop in pulmonary vascular resistance, suggesting at least regional vasodilation. Interestingly they also found a clear improvement in gas exchange, most likely triggered by several, but not clearly identified pathways.

There are reports were pulmonary vasodilators have improved clinical status of patients $(13,88-90)$, others have warned that pulmonary vasodilators can cause considerable pulmonary edema in patients with PVOD $(75,91-93)$. Day et al. (20) reported targeted $\mathrm{PH}$ therapy in pediatric patients before radiographic evidence of PVOD and $\mathrm{PCH}$ without development of pulmonary edema. However, in a single center experience, cautious use of epoprostenol improved exercise capacity in adult patients, but did not significantly reduce mean pulmonary arterial pressure (39). In a systematic review, the same group was unable to draw firm conclusion in the absence of randomized controlled trials with sufficient numbers of patients. Analyzing published case reports they suggested that vasodilator use may be effective in improving 6-minute walk distance, pulmonary vascular resistance, and survival in some patients, but they also highlighted the risk of pulmonary edema in many cases (94). Randomized controlled trials are lacking for patients with PVOD, hence the benefit of medical therapy with proven efficacy needs to be further evaluated. Genetic disposition may also play a role. Liang et al. reported on a favorable response to PAH-targeted therapy in a PVOD patient with biallelic EIF2AK4 mutation (95).

Case reports of adults with suspected PVOD by imaging implied improvement with sorafenib, a multikinase inhibitor (96) and imatinib a tyrosine kinase inhibitor $(97,98)$. Nifedipine seemed to have positive impact in an adult patient as well (99).

High-dose diuretics and supplemental oxygen may be used, whereas there is no proposed recommendation for anticoagulation or immunosuppressive therapy (81).

For adult patients, Wille et al. (100) suggest early referral for possible lung transplantation which could be considered for pediatric patients as well because of rapid disease progression and a higher risk for death while on the lung transplant waiting list.

In summary, distinguishing PVOD from other forms of pulmonary hypertension or chronic thromboembolic diseases is important, using all appropriate diagnostic tools. Medical treatment is limited with lung transplantation as a valid option.

\section{Acknowledgments}

Funding: None.

\section{Footnote}

Provenance and Peer Review: This article was commissioned by the Guest Editors (Christian Apitz and Astrid Lammers) 
for the series "Pediatric Pulmonary Hypertension" published in Cardiovascular Diagnosis and Therapy. The article has undergone external peer review.

Conflicts of Interest: Both authors have completed the ICMJE uniform disclosure form (available at http://dx.doi. org/10.21037/cdt-20-320). The series "Pediatric Pulmonary Hypertension" was commissioned by the editorial office without any funding or sponsorship. The authors have no other conflicts of interest to declare.

Ethical Statement: The authors are accountable for all aspects of the work in ensuring that questions related to the accuracy or integrity of any part of the work are appropriately investigated and resolved.

Open Access Statement: This is an Open Access article distributed in accordance with the Creative Commons Attribution-NonCommercial-NoDerivs 4.0 International License (CC BY-NC-ND 4.0), which permits the noncommercial replication and distribution of the article with the strict proviso that no changes or edits are made and the original work is properly cited (including links to both the formal publication through the relevant DOI and the license). See: https://creativecommons.org/licenses/by-nc-nd/4.0/.

\section{References}

1. Höra J. Zur Histologie der klinischen "primären Pulmonalsklerose”. Frankfurter Zeitschrift für Pathologie 1934;47:100-8.

2. Bürki K. Eine primäre isolierte obliterierende Pulmonalvenenveränderung als Ursache eines chronischen Cor pulmonale. Archiv für Kreislaufforschung 1963;40:35-68.

3. Heath D, Segel N, Bishop J. Pulmonary veno-occlusive disease. Circulation 1966;34:242-8.

4. Lantuéjoul S, Sheppard MN, Corrin B, et al. Pulmonary veno-occlusive disease and pulmonary capillary hemangiomatosis: a clinicopathologic study of 35 cases. Am J Surg Pathol 2006;30:850-7.

5. Simonneau G, Montani D, Celermajer DS, et al. Haemodynamic definitions and updated clinical classification of pulmonary hypertension. Eur Respir J 2019;53:1801913.

6. Palazzini M, Manes A. Pulmonary veno-occlusive disease misdiagnosed as idiopathic pulmonary arterial hypertension. Eur Respir Rev 2009;18:177-80.

7. Mandel J, Mark EJ, Hales CA. Pulmonary veno-occlusive disease. Am J Respir Crit Care Med 2000;162:1964-73.

8. Harch S, Whitford H, McLean C. Failure of medical therapy in pulmonary arterial hypertension. Is there an alternative diagnosis? Chest 2009;135:1462-9.

9. Berger RM, Beghetti M, Humpl T, et al. Clinical features of paediatric pulmonary hypertension: a registry study. Lancet 2012;379:537-46.

10. Weisser K, Wyler F, Gloor F. Pulmonary veno-occlusive disease. Arch Dis Child 1967;42:322-7.

11. Tingelstad JB, Aterman K, Lambert EC. Pulmonary venous obstruction. Report of a case mimicking primary pulmonary artery hypertension, with a review of the literature. Am J Dis Child 1969;117:219-27.

12. Woerner C, Cutz E, Yoo SJ, et al. Pulmonary venoocclusive disease in childhood. Chest 2014;146:167-74.

13. Holcomb BW Jr, Loyd JE, Ely EW, et al. Pulmonary veno-occlusive disease: a case series and new observations. Chest 2000;118:1671-9.

14. Montani D, Achouh L, Dorfmüller P, et al. Pulmonary veno-occlusive disease: clinical, functional, radiologic, and hemodynamic characteristics and outcome of 24 cases confirmed by histology. Medicine (Baltimore) 2008;87:220-33.

15. Matsushita K, Kanna M, Yazawa T, et al. Longterm survivor with pulmonary veno-occlusive disease. Circulation 2012;125:e503-6.

16. Allewelt H, Martin PL, Szabolcs P, et al. Hematopoietic stem cell transplantation for CD40 ligand deficiency: single institution experience. Pediatr Blood Cancer 2015;62:2216-22.

17. Cohn RC, Wong R, Spohn WA, et al. Death due to diffuse alveolar hemorrhage in a child with pulmonary venoocclusive disease. Chest 1991;100:1456-8.

18. Davies P, Reid L. Pulmonary veno-occlusive disease in siblings: case reports and morphometric study. Hum Pathol 1982;13:911-5.

19. Davis EM, Ramratnam SK, Spahr JE, et al. A typical case of atypical dyspnea. Ann Am Thorac Soc 2013;10:261-3.

20. Day RW, Clement PW, Hersh AO, et al. Pulmonary veno-occlusive disease: two children with gradual disease progression. Respir Med Case Rep 2016;20:82-6.

21. De Vries TW, Weening JJ, Roorda RJ. Pulmonary venoocclusive disease: a case report and a review of therapeutic possibilities. Eur Respir J 1991;4:1029-32.

22. Gupta SK, Saxena A, Gulati GS. Evaluation of pulmonary hypertension in a child: role of computed tomography. Indian J Pediatr 2011;78:1417-9.

23. Hackman RC, Madtes DK, Petersen FB, et al. 
Pulmonary venoocclusive disease following bone marrow transplantation. Transplantation 1989;47:989-92.

24. Heath D, Scott O, Lynch J. Pulmonary veno-occlusive disease. Thorax 1971;26:663-74.

25. Hussein A, Trowitzsch E, Brockmann M. Pulmonary veno-occlusive disease, antiphospholipid antibody and pulmonary hypertension in an adolescent. Klin Padiatr 1999;211:92-5.

26. Isshiki K, Shima H, Yamazaki F, et al. A Case of Pulmonary Veno-occlusive Disease Following Hepatic Veno-occlusive Disease After Autologous Hematopoietic Stem Cell Transplantation for Neuroblastoma. J Pediatr Hematol Oncol 2020;42:e677-9.

27. Justo RN, Dare AJ, Whight CM, et al. Pulmonary venoocclusive disease: diagnosis during life in four patients. Arch Dis Child 1993;68:97-100.

28. Kano G, Nakamura K, Sakamoto I. Pulmonary venoocclusive disease in an 11-year-old girl: diagnostic pitfalls. Pediatr Int 2014;56:119-22.

29. Kawashima N, Ikoma M, Sekiya Y, et al. Successful treatment of pulmonary hypertension with beraprost and sildenafil after cord blood transplantation for infantile leukemia. Int J Hematol 2013;97:147-50.

30. Liang CD, Huang SC, Su WJ. Pulmonary vascular obstructive disease and hemoptysis in a child with tetralogy of Fallot and patent ductus arteriosus. J Formos Med Assoc 1997;96:121-4.

31. Liebow AA, Carrington CB, Viamonte M. Intrapulmonary veno-obstructive disease. Circulation 1967;35:II-172.

32. Lombard CM, Churg A, Winokur S. Pulmonary venoocclusive disease following therapy for malignant neoplasms. Chest 1987;92:871-6.

33. Matsumoto JS, Hoffman AD. Pediatric case of the day. Pulmonary venoocclusive disease. AJR Am J Roentgenol 1993;160:1331-2.

34. Miyata D, Fukushima T, Matsunaga M, et al. Fatal pulmonary veno-occlusive disease after chemotherapy for Burkitt's lymphoma. Pediatr Int 2011;53:403-5.

35. Montani D, Girerd B, Jaïs X, et al. Clinical phenotypes and outcomes of heritable and sporadic pulmonary venoocclusive disease: a population-based study. Lancet Respir Med 2017;5:125-34.

36. Moreno-Galdó A, Torrent-Vernetta A, de Mir Messa I, et al. Use of inhaled iloprost in children with pulmonary hypertension. Pediatr Pulmonol 2015;50:370-9.

37. Muneuchi J, Oda S, Shimizu D. Rapidly progressive pulmonary veno-occlusive disease in an infant with Down syndrome. Cardiol Young 2017;27:1402-5.
38. Nohe N, Flemmer A, Rumler R, et al. The low molecular weight heparin dalteparin for prophylaxis and therapy of thrombosis in childhood: a report on 48 cases. Eur J Pediatr 1999;158 Suppl 3:S134-9.

39. Ogawa A, Miyaji K, Yamadori I, et al. Safety and efficacy of epoprostenol therapy in pulmonary veno-occlusive disease and pulmonary capillary hemangiomatosis. Circ J 2012;76:1729-36.

40. Rosenthal A, Vawter G, Wagenvoort CA. Intrapulmonary veno-occlusive disease. Am J Cardiol 1973;31:78-83.

41. Shrivastava S, Moller JH, Edwards JE. Congenital unilateral pulmonary venous atresia with pulmonary veno-occlusive disease in contralateral lung: an unusual association. Pediatr Cardiol 1986;7:213-9.

42. Swensen SJ, Tashjian JH, Myers JL, et al. Pulmonary venoocclusive disease: CT findings in eight patients. AJR Am J Roentgenol 1996;167:937-40.

43. Takahashi K, Chen F, Ikeda T, et al. Single-lobe lung transplantation for rapidly deteriorating pulmonary venoocclusive disease. Ann Thorac Surg 2013;95:689-91.

44. Tenorio J, Navas P, Barrios E, et al. A founder EIF2AK4 mutation causes an aggressive form of pulmonary arterial hypertension in Iberian Gypsies. Clin Genet 2015;88:579-83.

45. Trobaugh-Lotrario AD, Greffe B, Deterding R, et al. Pulmonary veno-occlusive disease after autologous bone marrow transplant in a child with stage IV neuroblastoma: case report and literature review. J Pediatr Hematol Oncol 2003;25:405-9.

46. Urisman A, Leard LE, Nathan M, et al. Rapidly progressive pulmonary venoocclusive disease in young women taking oral contraceptives. J Heart Lung Transplant 2012;31:1031-6.

47. Voordes CG, Kuipers JR, Elema JD. Familial pulmonary veno-occlusive disease: a case report. Thorax 1977;32:763-6.

48. Yang DT, Zhou H, Jaffe RB. Pathologic quiz case: a 6-year-old girl with progressive dyspnea. Pulmonary venoocclusive disease. Arch Pathol Lab Med 2003;127:e393-5.

49. Wagenvoort CA, Losekoot G, Mulder E. Pulmonary veno-occlusive disease of presumably intrauterine origin. Thorax 1971;26:429-34.

50. Stovin PG, Mitchinson MJ. Pulmonary hypertension due to obstruction of the intrapulmonary veins. Thorax 1965;20:106-13.

51. Brown CH, Harrison CV. Pulmonary veno-occlusive disease. Lancet 1966;2:61-5.

52. Bjornsson J, Edwards WD. Primary pulmonary 
hypertension: a histopathologic study of 80 cases. Mayo Clin Proc 1985;60:16-25.

53. Eyries M, Montani D, Girerd B, et al. EIF2AK4 mutations cause pulmonary veno-occlusive disease, a recessive form of pulmonary hypertension. Nat Genet 2014;46:65-9.

54. Eyries M, Montani D, Nadaud S, et al. Widening the landscape of heritable pulmonary hypertension mutations in paediatric and adult cases. Eur Respir J 2019;53:1801371.

55. Montani D, Lau EM, Descatha A, et al. Occupational exposure to organic solvents: a risk factor for pulmonary veno-occlusive disease. Eur Respir J 2015;46:1721-31.

56. Ranchoux B, Gunther S, Quarck R, et al. Chemotherapyinduced pulmonary hypertension: role of alkylating agents. Am J Pathol 2015;185:356-71.

57. Perros F, Günther S, Ranchoux B, et al. Mitomycininduced pulmonary veno-occlusive disease: evidence from human disease and animal models. Circulation 2015;132:834-47.

58. Bunte MC, Patnaik MM, Pritzker MR, et al. Pulmonary veno-occlusive disease following hematopoietic stem cell transplantation: a rare model of endothelial dysfunction. Bone Marrow Transplant 2008;41:677-86.

59. Kramer MR, Estenne M, Berkman N, et al. Radiationinduced pulmonary veno-occlusive disease. Chest 1993;104:1282-4.

60. Zinter MS, Melton A, Sabnis AJ, et al. Pulmonary venoocclusive disease in a pediatric hematopoietic stem cell transplant patient: a cautionary tale. Leuk Lymphoma 2018;59:1494-7.

61. Levy M, Moshous D, Szezepanski I, et al. Pulmonary hypertension after bone marrow transplantation in children. Eur Respir J 2019;54:1900612.

62. Dorfmüller P, Humbert M, Perros F, et al. Fibrous remodeling of the pulmonary venous system in pulmonary arterial hypertension associated with connective tissue diseases. Hum Pathol 2007;38:893-902.

63. Johnson SR, Patsios D, Hwang DM, et al. Pulmonary veno-occlusive disease and scleroderma associated pulmonary hypertension. J Rheumatol 2006;33:2347-50.

64. Hamada K, Teramoto S, Narita N, et al. Pulmonary veno-occlusive disease in pulmonary Langerhans' cell granulomatosis. Eur Respir J 2000;15:421-3.

65. Hoffstein V, Ranganathan N, Mullen JB. Sarcoidosis simulating pulmonary veno-occlusive disease. Am Rev Respir Dis 1986;134:809-11.

66. Kokturk N, Demir N, Demircan S, et al. Pulmonary venoocclusive disease in a patient with a history of Hashimoto's thyroiditis. Indian J Chest Dis Allied Sci 2005;47:289-92.

67. Jones RM, Dawson A, Jenkins GH, et al. Sarcoidosisrelated pulmonary veno-occlusive disease presenting with recurrent haemoptysis. Eur Respir J 2009;34:517-20.

68. Daraban AM, Enache R, Predescu L, et al. Pulmonary veno-occlusive disease: a rare cause of pulmonary hypertension in systemic sclerosis. Case presentation and review of the literature. Rom J Intern Med 2015;53:175-83.

69. Gupta S, Gupta A, Rehman S, et al. Pulmonary venoocclusive disease is highly prevalent in scleroderma patients undergoing lung transplantation. ERJ Open Res 2019;5:00168-2018.

70. Chetty R, Rose AG, Commerford PJ, et al. Pulmonary veno-occlusive disease associated with hypertrophic cardiomyopathy. Cardiovasc Pathol 1992;1:289-93.

71. Ali N, Loughborough WW, Rodrigues JCL, et al. Computed tomographic and clinical features of pulmonary veno-occlusive disease: raising the radiologist's awareness. Clin Radiol 2019;74:655-62.

72. Resten A, Maitre S, Humbert M, et al. Pulmonary hypertension: CT of the chest in pulmonary venoocclusive disease. AJR Am J Roentgenol 2004;183:65-70.

73. Berteloot L, Proisy M, Jais JP, et al. Idiopathic, heritable and veno-occlusive pulmonary arterial hypertension in childhood: computed tomography angiography features in the initial assessment of the disease. Pediatr Radiol 2019;49:575-85.

74. Cassart M, Gevenois PA, Kramer M, et al. Pulmonary venoocclusive disease: CT findings before and after single-lung transplantation. AJR Am J Roentgenol 1993;160:759-60.

75. Dufour B, Maitre S, Humbert M, et al. High-resolution CT of the chest in four patients with pulmonary capillary hemangiomatosis or pulmonary venoocclusive disease. AJR Am J Roentgenol 1998;171:1321-4.

76. Hadinnapola C, Bleda M, Haimel M, et al. Phenotypic characterization of EIF2AK4 mutation carriers in a large cohort of patients diagnosed clinically with pulmonary arterial hypertension. Circulation 2017;136:2022-33.

77. Rabiller A, Jaîs X, Hamid A, et al. Occult alveolar haemorrhage in pulmonary veno-occlusive disease. Eur Respir J 2006;27:108-13.

78. Bailey CL, Channick RN, Auger WR, et al. "High probability" perfusion lung scans in pulmonary venoocclusive disease. Am J Respir Crit Care Med 2000;162:1974-8.

79. Jaklitsch MT, Linden BC, Braunlin EA, et al. Open- 
lung biopsy guides therapy in children. Ann Thorac Surg 2001;71:1779-85.

80. Carmosino MJ, Friesen RH, Doran A, et al. Perioperative complications in children with pulmonary hypertension undergoing noncardiac surgery or cardiac catheterization. Anesth Analg 2007;104:521-7.

81. Galiè N, Humbert M, Vachiery JL, et al. 2015 ESC/ERS Guidelines for the diagnosis and treatment of pulmonary hypertension: The Joint Task Force for the Diagnosis and Treatment of Pulmonary Hypertension of the European Society of Cardiology (ESC) and the European Respiratory Society (ERS): Endorsed by: Association for European Paediatric and Congenital Cardiology (AEPC), International Society for Heart and Lung Transplantation (ISHLT). Eur Respir J 2015;46:903-75.

82. Lederer H, Muggli B, Speich R, et al. Haemosiderin-laden sputum macrophages for diagnosis in pulmonary venoocclusive disease. PLoS One 2014;9:e115219.

83. Beghetti M, Berger RM, Schulze-Neick I, et al. Diagnostic evaluation of paediatric pulmonary hypertension in current clinical practice. Eur Respir J 2013;42:689-700.

84. Ogawa A, Takahashi Y, Matsubara H. Clinical prediction score for identifying patients with pulmonary venoocclusive disease/pulmonary capillary hemangiomatosis. J Cardiol 2018;72:255-60.

85. Hoopes CW, Gurley JC, Zwischenberger JB, et al. Mechanical support for pulmonary veno-occlusive disease: combined atrial septostomy and venovenous extracorporeal membrane oxygenation. Semin Thorac Cardiovasc Surg 2012;24:232-4.

86. Taylor K, Holtby H. Emergency interventional lung assist for pulmonary hypertension. Anesth Analg 2009; 109:382-5.

87. Hoeper MM, Eschenbruch C, Zink-Wohlfart C, et al. Effects of inhaled nitric oxide and aerosolized iloprost in pulmonary veno-occlusive disease. Respir Med 1999;93:62-4.

88. Okumura H, Nagaya N, Kyotani S, et al. Effects of continuous IV prostacyclin in a patient with pulmonary veno-occlusive disease. Chest 2002;122:1096-8.

89. Barreto AC, Franchi SM, Castro CR, et al. One-year

Cite this article as: Pfluger M, Humpl T. Pulmonary venoocclusive disease in childhood-a rare disease not to be missed. Cardiovasc Diagn Ther 2021;11(4):1070-1079. doi: 10.21037/ cdt-20-320 follow-up of the effects of sildenafil on pulmonary arterial hypertension and veno-occlusive disease. Braz J Med Biol Res 2005;38:185-95.

90. Chamorro Fernández CI, Garcés Cabello P, Pérez Mateos $\mathrm{R}$, et al. The first experience of pulmonary veno-occlusive disease treatment with macitentan and sildenafil. Rev Esp Cardiol (Engl Ed) 2017;70:396-7.

91. Palmer SM, Robinson LJ, Wang A, et al. Massive pulmonary edema and death after prostacyclin infusion in a patient with pulmonary veno-occlusive disease. Chest 1998;113:237-40.

92. Humbert M, Maître S, Capron F, et al. Pulmonary edema complicating continuous intravenous prostacyclin in pulmonary capillary hemangiomatosis. Am J Respir Crit Care Med 1998;157:1681-5.

93. Creagh-Brown BC, Nicholson AG, Showkathali R, et al. Pulmonary veno-occlusive disease presenting with recurrent pulmonary oedema and the use of nitric oxide to predict response to sildenafil. Thorax 2008;63:933-4.

94. Ogawa A, Sakao S, Tanabe N, et al. Use of vasodilators for the treatment of pulmonary veno-occlusive disease and pulmonary capillary hemangiomatosis: a systematic review. Respir Investig 2019;57:183-90.

95. Liang L, Su H, Ma X, et al. Good response to PAHtargeted drugs in a PVOD patient carrying Biallelic EIF2AK4 mutation. Respir Res 2018;19:192.

96. Kataoka M, Yanagisawa R, Fukuda K, et al. Sorafenib is effective in the treatment of pulmonary veno-occlusive disease. Cardiology 2012;123:172-4.

97. Overbeek MJ, van Nieuw Amerongen GP, Boonstra A, et al. Possible role of imatinib in clinical pulmonary venoocclusive disease. Eur Respir J 2008;32:232-5.

98. Sato H, Sugimura K, Miura M, et al. Beneficial effects of imatinib in a patient with suspected pulmonary venoocclusive disease. Tohoku J Exp Med 2019;247:69-73.

99. Salzman GA, Rosa UW. Prolonged survival in pulmonary veno-occlusive disease treated with nifedipine. Chest 1989;95:1154-6.

100. Wille KM, Sharma NS, Kulkarni T, et al. Characteristics of patients with pulmonary venoocclusive disease awaiting transplantation. Ann Am Thorac Soc 2014;11:1411-8. 